\title{
Seosrehun tärkkelyspitoisuuden vaikutus lehmien liikkumisaktiivisuuteen ja maitotuotokseen automaattilypsynavetassa
}

\author{
Seija Jaakkola ${ }^{1}$, Tuomo Kokkonen ${ }^{1}$, Marjo Toivonen ${ }^{1}$ ja Lea Puumala ${ }^{2}$ \\ ${ }^{1)}$ Helsingin yliopisto, Maataloustieteiden laitos, PL 28 (Koetilantie 5), 00014 Helsingin yliopisto \\ etunimi.sukunimi@helsinki.fi \\ ${ }^{2)}$ TTS Työtehoseura, c/o Maitosuomi, PL 337, 60101 Seinäjoki
}

\section{Tiivistelmä}

Hyvin toimiva automaattilypsy edellyttää, että lehmät menevät vapaaehtoisesti lypsettäväksi. Lypsyn aikana annettava väkirehu houkuttelee lehmän lypsylle, jos lehmän rehun saantihalu ei tule tyydytettyä ruokintapöydän tai väkirehukioskin rehuista. Ruokintapöydältä tarjottavan seosrehun koostumuksen on esitetty vaikuttavan lehmäliikenteeseen eli lehmien liikkumisaktiivisuuteen. Tässä tutkimuksessa selvitettiin seosrehun tärkkelyspitoisuuden vaikutusta rehun syöntiin, maitotuotokseen ja lehmien vapaaehtoiseen kulkuun lypsyrobotille.

Tutkimus tehtiin Helsingin yliopiston Viikin opetus- ja tutkimustilan navetassa syksyllä 2012. Pihaton kaikki lehmät olivat koeruokinnalla, mutta tulokset laskettiin vain sopivassa tuotosvaiheessa olevilta 39 lehmältä. Poikimisesta oli kulunut keskimäärin 104 päivää kokeen alkaessa. Kokeessa oli kolme kahden viikon jaksoa. Ensimmäisellä jaksolla lehmät saivat tärkkelyspitoista seosrehua $(\mathrm{T})$, toisella jaksolla osa tärkkelyksestä korvattiin kuidulla $(\mathrm{K})$ ja viimeisellä jaksolla lehmät palasivat tärkkelyspitoiselle ruokinnalle $(\mathrm{T})$. Tärkkelyspitoisuuden muutos toteutettiin korvaamalla puolet seosrehun viljasta kuitupitoisemmalla väkirehulla. Seosrehussa oli väkirehua $42 \%$ ja käymislaadultaan sekä sulavuudeltaan hyvää (D-arvo $727 \mathrm{~g} / \mathrm{kg} \mathrm{ka}$ ) nurmisäilörehua $58 \%$ kuiva-aineesta. Lisäksi lehmät saivat lypsyjen aikana teollista täysrehua, jonka annos vakioitiin lehmittäin maitotuotoksen mukaan (4, 6 tai $8 \mathrm{~kg} / \mathrm{pv}$ ). Lehmät lypsettiin automaattisessa lypsyjärjestelmässä, jossa eläinten kulku oli täysin vapaa. Lehmien haku lypsyrobotille vakioitiin hakuaikojen ja haun syyn suhteen (lypsystä yli 11 tuntia). Jakson ja samalla ruokinnan vaikutus lehmien lypsy-, tuotos- ja syöntitietoihin analysoitiin regressioanalyysilla SAS:in Mixed-proseduurilla.

Tärkkelyspitoisuudet olivat koko rehuannoksessa (seosrehu + robottiväkirehu) keskimäärin 193 (T) ja 127 (K) g/kg ka, seosrehussa 172 (T) ja 87 (K) g/kg ka ja väkirehussa (robotti+seosrehu) 354 (T) ja 233 (K) g/kg ka. Kokeen aikana ruokinnan väkirehuosuus oli 54,7 \% kuiva-aineesta ja robottirehun osuus väkirehusta $40 \%$. Seosrehun syöntimäärä $(18,9 \mathrm{~kg}$ ka) ja syöntikerrat päivässä pysyivät hyvin tasaisena koko kokeen ajan. Maitotuotos $(40,4-39,3-38,6 \mathrm{~kg} / \mathrm{pv})$ ja robottilypsyjen määrä $(3,12$ $3,03-2,89 \mathrm{kpl} / \mathrm{pv}$ ) vähenivät lineaarisesti kokeen aikana siirryttäessä jaksolta 1 jaksolle 3 muutosten kuvatessa lähinnä lypsykauden etenemistä. Tulosten perusteella tärkkelyspitoisempi seosrehu ei vähentänyt tuotosta tai lypsykertoja kuituruokintaan verrattuna. Koelehmien hakukertoja lypsylle oli hieman vähemmän jaksolla 2 kuin jaksoilla 1 ja $3(0,15-0,12-0,16$ kertaa/lehmä/päivä), mikä tarkoitti 39 koelehmän ryhmässä noin 1,4 hakukertaa vähemmän päivässä lehmien saadessa kuitupitoisempaa rehua. Tässä kokeessa käytetty tärkkelyspitoisempi seosrehu ei lisännyt oleellisesti lehmien hakutarvetta lypsyrobotille eikä vähentänyt seosrehun syöntiä kuitupitoisempaan rehuun verrattuna.

Asiasanat: automaattinen lypsyjärjestelmä, lypsylehmä, seosrehu, tärkkelys, eläinliikenne 


\section{Johdanto}

Automaattilypsynavetan toiminta perustuu pitkälti lehmän motivaatioon ja mahdollisuuteen mennä syömään ja lypsylle. Hyvin toimivassa automaattilypsyssä lehmät menevät vapaaehtoisesti, säännöllisesti ja riittävän usein lypsettäväksi. Tuloksena on hyvä maitotuotos ja vähäinen työtarve eläinten hakuun lypsylle. Robottinavetassa lypsy liittyy kiinteästi lehmän syöntikäyttäytymiseen ja ruokinnan järjestämiseen. Lehmän halu syödä lypsyrobotista annettavaa väkirehua on vapaan lehmäliikenteen navetassa ensisijainen tekijä, joka houkuttelee lehmän lypsylle (Prescott ym. 1998a, Bach ym. 2007). Kulkuaktiivisuutteen voi vaikutta myös robottirehun olomuoto (Rodenburg ym. 2004) ja koostumus (Madsen ym. 2010). Prescottin ym. (1998b) mukaan lehmän motivaatio mennä lypsyrobottiin heikkenee, jos rehun saantihalu tulee liiaksi tyydytettyä muualla eli ruokintapöydän tai väkirehukioskin rehuista. Ohjattu järjestelmä perustuu vapaata järjestelmää vähemmän lehmän valinnanvapauteen. Erilaisissa ohjatuissa järjestelmissä lypsyjen määrä pyritään pitämään sopivana lehmien kulunohjauksen ja ohjausporttien avulla. Järjestelmät ohjaavat lehmää lypsylle rajoittamalla vapaata pääsyä syömään ruokintapöydälle ja/tai väkirehukioskiin tai pääsyä makuualueelle ruokinta-alueelta. Liikenneohjauksen (vapaa, ohjattu, osittain ohjattu) ja ruokinnan lisäksi eläinten liikkumiseen vaikuttavat muun muassa navetan olosuhteet ja robotin kapasiteetti suhteessa eläinmäärään ja tuotostasoon. Kyseessä on monimuotoinen kokonaisuus, jossa eläimen rehunsyönti, maitotuotos ja terveys vaikuttavat toisiinsa.

Ruokintapöydältä tarjottavan seosrehun koostumuksen on esitetty vaikuttavan lehmien liikkumisaktiivisuuteen eli haluun mennä lypsylle ja syömään (Rodenburg 2011). Seosrehun koostumuksen vaikutusta lehmäliikenteeseen on kuitenkin tutkittu erittäin vähän. Lehmien aktiivisuuden huomioivat ruokintasuositukset perustuvat pääasiassa käytännössä saatuihin kokemuksiin. Tässä tutkimuksessa selvitettiin seosrehun tärkkelyspitoisuuden vaikutusta lehmien syönti- ja lypsyaktiivisuuteen sekä tuotokseen, kun automaattilypsy perustuu täysin vapaaseen lehmäliikenteeseen.

\section{Aineisto ja menetelmät}

Tutkimus tehtiin Helsingin yliopiston maataloustieteiden laitoksella Viikin opetus- ja tutkimustilan navetassa 20.11. - 31.12.2012. Tutkimuksessa oli 39 lehmää, joista ensikoita oli 15 ja vanhempia lehmiä 24. Kaikki robottilypsyssä olleet navetan lehmät (keskimäärin 54) söivät samoja koerehuja. Tulokset laskettiin kuitenkin vain niiltä lehmiltä, joiden poikimisesta oli kulunut vähintään kolme viikkoa ja jotka eivät olleet menossa umpeen kokeen aikana. Pääasiassa koelehmät olivat tuotoskauden alkutai keskivaiheessa, sillä vain viiden lehmän poikimisesta oli kokeen alkaessa kulunut yli 200 päivää. Keskimäärin poikimisesta oli kulunut 104 (keskihajonta 91,8) päivää kokeen alkaessa.

Kokeessa oli kolme kahden viikon jaksoa. Ensimmäinen viikko jaksosta oli totutuskautta. Toinen viikko oli koekausi, jolta laskettiin tulokset. Kaikki lehmät olivat ensimmäisen jakson ruokinnalla A (seosrehu A [Tärkkelys]+ robottiväkirehu). Tämän jälkeen lehmät siirtyivät toisen jakson ajaksi ruokinnalle B (seosrehu B [Kuitu]+ robottiväkirehu) ja viimeisen jakson ajaksi alkuperäiselle ruokinnalle A. Siirtyminen ruokinnalta toiselle tehtiin vähitellen 3-5 päivän aikana. Seosrehut A ja B erosivat toisistaan tärkkelys- ja kuitupitoisuuden (NDF) suhteen. Ruokinnat suunniteltiin niin, että koko rehuannoksen (seosrehu + robottiväkirehu) tärkkelyspitoisuudet olisivat noin 200 (A) tai 150 (B) g/kg kuiva-ainetta (ka) ja vastaavasti seosrehun tärkkelyspitoisuudet noin 165 (A) ja 95 (B) g/kg ka. Seosrehun tärkkelyspitoisuuden muutos toteutettiin korvaamalla viljaa kuitupitoisella väkirehulla (Leikekuituseos, A-rehu Oy) (taulukko 1), joka sisälsi pääasiassa melassileikettä ja ohrarehua. Valkuaisrehun (Rypsitiiviste, A-rehu Oy) osuus seoksessa pysyi samana koko kokeen ajan. Seosrehussa oli väkirehua $42 \%$ ja nurmisäilörehua $58 \%$ kuiva-aineesta. Säilörehu oli laakasiiloon säilöttyä, noukinvaunulla korjattua timotei-nurminatarehua, jonka säilönnässä käytettiin muurahaishappopohjaista säilöntäainetta (AIV2 Plus, Kemira Oyj).

Seosrehu tehtiin ja jaettiin punnitsevalla ja sekoittavalla kiskoruokkijalla (TMR sukkula, Pellon Group Oy). Rehu jaettiin ruokintapöydällä oleviin vaa'alla varustettuihin rehukuppeihin ( $22 \mathrm{kpl})$, joissa on automaattinen rehunkulutuksen seurantajärjestelmä (RIC, Roughage Intake Control, Insentec, Hollanti). Vaakakupit ohjelmoitiin niin, että kaikki eläimet saivat syödä kaikista kupeista vapaasti seosrehua ympäri vuorokauden ilman aika- tai määrärajoituksia. Rehua jaettiin viisi kertaa päivässä eli klo 3, klo 9.30, 12.30, 17.30 ja 22. Lehmät eivät päässeet syömään vaunun jakaessa rehua ja kuppien tyhjennyksen aikana (klo 9-9.30). Jaettava rehumäärä säädettiin niin, että rehukupeissa oli aina rehua. 
Taulukko 1. Seosrehussa käytetyn väkirehun koostumus (\% ilmakuivasta rehusta)

\begin{tabular}{lcc}
\hline & $\begin{array}{c}\text { Seos A } \\
\text { Tärkkelys }\end{array}$ & $\begin{array}{c}\text { Seos B } \\
\text { Kuitu }\end{array}$ \\
\hline Kaura & 10 & 5 \\
Ohra & 57 & 28,5 \\
Leike-kuituseos & - & 33,5 \\
Rypsitiiviste & 30 & 30 \\
Kivennäisseos & 3 & 3 \\
\hline
\end{tabular}

Seosrehun lisäksi lehmät saivat lypsyn yhteydessä täysrehua (Tekno-täysrehu, A-rehu Oy). Rehun päiväannos määriteltiin yksittäisen lehmän maitotuotoksen mukaan kokeen alussa seuraavasti: maitotuotos 25-35 kg väkirehua $4 \mathrm{~kg}$ (9 lehmää), tuotos 35-45 kg väkirehua $6 \mathrm{~kg}$ (12 lehmää) ja tuotos yli $45 \mathrm{~kg}$ väkirehua $8 \mathrm{~kg}$ (18 lehmää). Rehumäärää ei muutettu kokeen aikana. Väkirehun syöttö oli rajoitettu niin, että lehmä sai yhdellä lypsykerralla enintään $3 \mathrm{~kg}$.

Lehmät lypsettiin automaattisessa lypsyjärjestelmässä (Lely Astronaut A3), jossa lehmien kulku lypsylle ja syömään ruokintapöydälle oli täysin vapaa. Lypsy sallittiin aikaisintaan kuusi tuntia edellisestä lypsystä ja lypsykertoja oli enintään neljä vuorokaudessa. Lehmien haku lypsyrobotille vakioitiin neljään hakuaikaan päivässä ja hakusyyt määriteltiin. Lehmä haettiin lypsylle vain, jos edellisestä lypsystä oli kulunut vähintään 11 tuntia.

Seosrehun syöntimäärä, syöntikertojen määrä, syönnin kesto ja ajoitus sekä syöntinopeus määritettiin päiväkohtaisesti. Yhdeksi syöntikerraksi yhdistettiin käynnit rehukupilla, jos käyntien välinen aika oli lyhyempi kuin 5 minuuttia. Väkirehun kulutus lypsyn yhteydessä saatiin lypsyrobotin hallintaohjelman keräämistä tiedoista. Lisäksi väkirehun todellista syöntiä seurattiin videoinnin avulla. Myös maitomäärä, muut lypsyyn liittyvät tiedot (robottiin tulon ja robotista lähdön kellonaika, läpikulut, epäonnistuneet lypsyt, lypsyaika, maidon virtausnopeus) ja elopaino saatiin lypsyrobotin tiedonkeruuohjelmasta. Lehmien määrää robotin edustalla tarkkailtiin videotallenteiden avulla. Tavoitteena oli selvittää lehmien jonotusta robotille. Maitonäytteet otettiin jokaisen jakson toisella viikolla näytteenottolaitteella tuotannonseurantanäytteiden ottotavan mukaisesti. Näytteistä määritettiin rasva, valkuainen, urea ja solut. Rasvapitoisuus korjattiin Maatalouden Laskentakeskuksessa tuotosseurannassa käytettävällä laskentatavalla. Seosrehusta, säilörehusta, seosrehun väkirehusta ja robottiväkirehusta otettiin näytteet jokaiselta jaksolta. Näytteistä analysoitiin kemiallinen koostumus ja säilörehusta lisäksi Darvo ja käymislaatu.

Jakson ja ruokinnan vaikutus tuloksiin analysoitiin regressioanalyysillä käyttäen SAS Mixedproseduuria. Aluksi testattiin tutkittujen muuttujien osalta kovariaattien (poikimakerta, aika poikimisesta, robottiväkirehun määrä) ja jakson yhdysvaikutusta. Testissä selvitettiin oliko ruokinnan muutoksen (Tärkkelys->Kuitu->Tärkkelys) vaikutus erilainen eri-ikäisiin, eri tuotosvaiheessa oleviin ja eri määrän robottirehua saaviin lehmiin. Tilastollisesti merkitseviä olivat yhdysvaikutukset maidon virtausnopeus x poikimakerta ja lypsyväli x aika poikimisesta. Lopullisessa analyysissa testattiin jakson ja muuttujien välistä yhteyttä lineaarisen ja toisen asteen regressioanalyysin avulla. Jos testissä ei todettu merkitsevää toisen asteen vaikutusta, on tuloksissa esitetty vain lineaarisen testin tulokset. Lineaarinen vaikutus (merkitsevyys $\mathrm{P}_{\mathrm{L}}$ ) osoittaa, ettei jakso 2 (kuituruokinta) muuttanut tutkittavaa tekijää jaksoihin 1 ja 3 (tärkkelysruokinnat) verrattuna. Toisen asteen (käyräviivainen) vaikutus $\left(\mathrm{P}_{\mathrm{Q}}\right)$ osoittaa kuituruokinnan mahdollisesti aiheuttaman merkitsevän muutoksen verrattuna tärkkelysruokintoihin.

\section{Tulokset ja niiden tarkastelu}

Robottinavetassa oli koelehmien lisäksi myös karjan muut lehmät. Olosuhteet pyrittiin pitämään mahdollisimman tasaisena koko kokeen ajan. Keskimäärin koejaksoilla 1-3 oli robottilypsyssä lehmiä yhteensä 52-55-56, lypsyjen määrä päivässä oli 150-151-150, maitoa tuotettiin 1991-2036-2122 kg ja robotin vapaa kapasiteetti oli 9,8-8,4-5,7\%.

Säilörehun ruokinnallinen arvo oli hyvä sekä käymislaadun että sulavuuden osalta (taulukko 2). Kolmannella jaksolla säilörehun raakavalkuaispitoisuus oli suurempi kuin muilla jaksolla. Käymislaatu ja D-arvo pysyivät kuitenkin hyvin samanlaisena koko kokeen ajan. Tavoitteena ollut ruokinnan 
tärkkelyspitoisuuden ero jaksojen välillä saavutettiin melko hyvin. Seosrehun tärkkelyspitoisuus oli 166, 87 ja 177 g/kg ka (taulukko 3) ja koko ruokinnan189, 127 ja $197 \mathrm{~g} / \mathrm{kg}$ ka (taulukko 4) jaksoilla 13. Kokeen aikana ruokinnan väkirehuosuus oli keskimäärin 54,7 \% kuiva-aineesta ja robottirehun osuus väkirehusta $40 \%$ sekä koko rehumäärästä $22 \%$ kuiva-aineesta. Kun robottirehun annos oli 4, 6 tai $8 \mathrm{~kg} / \mathrm{pv}$ oli vastaavasti rehun osuus koko ruokinnasta 16,22 ja $25 \%$.

Rehujen syöntimäärät ja syöntikerrat pysyivät tasaisena kokeen ajan (taulukot 4 ja 6). Siirtyminen kuituruokinnalle ja siltä pois ei aiheuttanut muutosta rehujen syöntiin tai syöntikertoihin. Videoinnin perusteella lehmät ehtivät syödä robottirehun lypsyn aikana. Laskettuna keskimääräisen robotissa oloajan ja lypsykerralla pudotetun rehumäärän perusteella tämä edellytti 220-300 g/min syöntinopeutta robottirehun määrä ollessa $4-8 \mathrm{~kg} / \mathrm{pv}$. Ravintoaineiden saannissa todettiin käyräviivaisia muutoksia. Koeasetelman mukaisesti tärkkelyksen syönti ja pitoisuus rehuannoksessa oli pienin ja NDF:n vastaavasti suurin toisella koejaksolla $\left(\mathrm{P}_{\mathrm{Q}}<0,001\right)$. Raakavalkuaisen syönnin ja pitoisuuden lisääntyminen kolmannella jaksolla $\left(\mathrm{P}_{\mathrm{Q}}<0,001\right)$ ei johtunut koeasetelmasta vaan säilörehun valkuaispitoisuuden muutoksesta. Myös kolmannella jaksolla todettu seosrehun nopeampi syönti muihin jaksoihin verrattuna $\left(\mathrm{P}_{\mathrm{Q}}<0,001\right)$ liittyi todennäköisesti muihin tekijöihin kuten säilörehun koostumukseen tai lehmien hieman suurempaan kokonaismäärään navetassa.

Maitotuotos ja lypsyjen määrä päivässä $(\mathrm{P}<0,001)$ vähenivät ja lypsyväli $(\mathrm{P}<0,05)$ piteni lineaarisesti kokeen aikana (taulukot 4-6). Koska maidon rasvapitoisuus lisääntyi $\left(\mathrm{P}_{\mathrm{L}}<0,001\right)$, ei energiakorjatussa maitotuotoksessa $(\mathrm{EKM})$ ollut suurta eroa jaksojen välillä $(\mathrm{P}>0,05)$. Kolmannen jakson EKMtuotos oli keskimäärin 98,4 \% ensimmäisen jakson tuotoksesta. Lievä tuotoksen väheneminen vastaa normaalia tuotantokauden etenemisen aiheuttamaa muutosta kuukauden aikana. Lypsyväli piteni selkeimmin lehmillä, joiden poikimisesta oli yli 200 päivää kokeen alkaessa. Lypsyrobotin vapaan kapasiteetin pieneneminen kokeen aikana saattoi osaltaan vaikuttaa lypsykertojen vähenemiseen. Tätä kuitenkin kompensoi se, että yhdellä lypsykerralla tuotettu maitomäärä lisääntyi $\left(\mathrm{P}_{\mathrm{L}}=0,07\right)$ (taulukko 6). Samalla myös yhden lypsykerran lypsyaika piteni $\left(\mathrm{P}_{\mathrm{L}}<0,05\right)$. Tulosten perusteella tärkkelyspitoisempi seosrehu ei vähentänyt lypsykertoja ja tuotosta kuitupitoisempaan ruokintaan verrattuna.

Kuitupitoisempi ruokinta vähensi hieman maidon valkuaispitoisuutta tärkkelysruokintaan verrattuna $\left(\mathrm{P}_{\mathrm{Q}}<0,01\right)$. Koko rehuannoksen ME-pitoisuus oli pienempi kuitujaksolla kuin tärkkelysjaksoilla, mutta energian saannissa ei kuitenkaan ollut eroa. Hieman runsaampi syönti kompensoi kuituruokinnan pienempää ME-pitoisuutta. Maidon ureapitoisuuden käyräviivainen $\left(\mathrm{P}_{\mathrm{Q}}<0,001\right)$ muutos johtuu säilörehun suuremmasta valkuaispitoisuudesta kolmannella jaksolla. Vanhempien lehmien maidon virtausnopeudessa ei ollut eroa jaksojen välillä, mutta ensikoiden maidon virtausnopeus lisääntyi lineaarisesti $\left(\mathrm{P}_{\mathrm{L}}<0,05\right)$. Maidon maksimivirtausnopeus oli suurempi kuituruokinnan yhteydessä verrattuna tärkkelyspitoisempaan ruokintaan $\left(\mathrm{P}_{\mathrm{Q}}<0,001\right)$.

Ruokintajakson vaikutus lehmien hakuun lypsylle ei ollut tilastollisesti merkitsevä $\left(\mathrm{P}_{\mathrm{L}}\right.$, $\mathrm{P}_{\mathrm{Q}}>0$,05). Lehmiä jouduttiin kuitenkin hakemaan lypsylle hieman useammin seosrehun sisältäessä enemmän tärkkelystä (taulukko 6). Haettujen lypsyjen osuus kaikista lypsyistä oli ensimmäisellä jaksolla 4,8 \% (ensikot 9,0 \% ja vanhemmat 2,5\%), toisella jaksolla 4,1 \% (5,7 ja 3,2) ja kolmannella jaksolla 5,6 \% (9,2 ja 3,7). Ensikoiden keskimäärin suurempi hakutarve vanhempiin lehmiin verrattuna saattaa liittyä lypsyrobotin vapaaseen kapasiteettiin, joka oli kokeen aikana keskimäärin $8 \%$ eli noin 2 tuntia päivässä. Ensikot ovat hierarkiassa vanhempia lehmiä alempana ja lypsylle pääsy voi vaikeutua jonotustilanteissa. Toisaalta suurinta osaa ensikoista (10 ensikkoa 15:sta) ei jouduttu hakemaan yhtään kertaa lypsylle koeviikoilla.

Yhteensä lypsylle hakuja oli 39 koelehmän ryhmässä yhden päivän aikana keskimäärin 5,8, 4,8 ja 6,3 jaksoilla 1-3 eli kuitujaksolla oli keskimäärin vain 1,3 hakua vähemmän kuin tärkkelysjaksoilla. Suurempi hakutarve tärkkelysjaksoilla koski selvästi vain kahta ensikkoa, jotka haettiin lypsylle molemmilla tärkkelysjaksoilla keskimäärin 1,2 kertaa päivässä. Kuitujaksolla toinen ensikoista haettiin lypsylle keskimäärin 0,2 ja toinen 0,5 kertaa päivässä. Kyseisten ensikoiden poikimisesta oli kolme kuukautta kokeen alussa ja ne olivat oppineet robotilla käynnin. Lehmien jonottamisessa lypsyrobotille ei todettu merkitseviä muutoksia jaksojen välillä. Lehmämäärä robotin edustalla tosin hieman lisääntyi olleen keskimäärin 1,9, 2,0 ja 2,3 jaksoilla 1-3. Tilastollisessa testauksessa navetan lehmämäärän lievä lisääntyminen ei selittänyt muutosta jonottajien määrässä. 


\section{Johtopäätökset}

Tutkimuksessa käytetty tärkkelyspitoisempi seosrehu ei lisännyt oleellisesti lehmien hakutarvetta lypsyrobotille eikä vähentänyt seosrehun syöntiä, syöntikertoja tai tuotosta kuitupitoisempaan rehuun verrattuna. Vain kahden yksittäisen ensikon lypsyaktiivisuus heikkeni selkeästi tärkkelyspitoisen ruokinnan yhteydessä. Seosrehun koostumuksen vaikutus lehmien vapaaehtoiseen kulkuun lypsylle on tämän perusteella yksilöllistä. Tuloksen tulkinnassa on otettava huomioon, että säilörehu oli sulavuudeltaan ja käymisladultaan hyvää, lehmät olivat pääasiassa tuotoskauden alku- tai keskivaiheessa, tärkkelyspitoisempi seosrehu sisälsi tärkkelystä $172 \mathrm{~g} / \mathrm{kg}$ ka ja robottiväkirehun osuus koko ruokinnassa oli keskimäärin $22 \%$. Näiden yksittäisten tekijöiden muuttuessa tulos voi olla erilainen.

\section{Kirjallisuus}

Madsen, J., Weisbjerg, M.R. \& Hvelplund, T. 2010. Concentrate composition for Automatic Milking Systems - Effect on milking frequency. Livestock Science 127: 45-50.

Prescott, N.B., Mottram, T.T. \& Webster, A.J.F. 1998a. Relative motivations of dairy cows to be milked or fed in a Y-maze and an automatic milking system. Applied Animal Behaviour Science 57: 23-33.

Prescott, N.B., Mottram, T.T. \& Webster, A.J.F. 1998b. Effect of food type and location on the attendance to an automatic milking system by dairy cows and the effect of feeding during milking on their behavior and milking characteristics. Animal Science 67: 183-193.

Rodenburg, J., Focker, E. \& Hand, K. 2004. Effect of the composition of concentrate fed in the milking box, on milking frequency and voluntary attendance in automatic milking systems. A better understanding: Automatic Milking. Toim. Meijering, A., Hogeveen, H. \& de Koning, C.J.A.M. s. 511.

Rodenburg, J. 2011. Designing Feeding Systems for Robotic Milking. Tri-State Nutrition Conference 19.20.4.2011. s. 127- 138. Viitattu 11.12.2013. Saatavissa: http://tristatedairy.osu.edu/Proceedings\%202011/ Rodenburg\%20paper.pdf

Taulukko 2. Säilörehun koostumus (g/kg ka, jos muuta ei mainittu) ja rehuarvot.

\begin{tabular}{lccc}
\hline & Jakso 1 & Jakso 2 & Jakso 3 \\
\hline Kuiva-aine, g/kg & 222 & 225 & 224 \\
Tuhka & 68,6 & 69,0 & 71,0 \\
Raakavalkuainen & 141 & 135 & 171 \\
NDF & 542 & 547 & 523 \\
pH & 3,88 & 3,93 & 3,90 \\
Sokeri & 48,7 & 48,4 & 63,7 \\
Maitohappo & 60,2 & 60,0 & 44,3 \\
Etikkahappo & 9,71 & 12,1 & 8,70 \\
Ammonium-N, g/kg N & 51,1 & 52,6 & 45,9 \\
D-arvo & 725 & 723 & 729 \\
Syönti-indeksi & 107 & 106 & 110 \\
ME, MJ/kg ka & 11,6 & 11,6 & 11,7 \\
OIV & 85,5 & 84,7 & 89,2 \\
PVT & 12,7 & 7,54 & 38,2 \\
Säilörehun NDF, \% koko ruo- & 23,6 & 23,9 & 22,9 \\
kinnan kuiva-aineesta & & & \\
\hline
\end{tabular}

Taulukko 3. Väkirehujen ja seosrehun koostumus (g/kg ka, jos muuta ei mainittu) ja rehuarvot.

\begin{tabular}{|c|c|c|c|c|c|c|c|}
\hline & \multirow{2}{*}{$\begin{array}{l}\text { Robotti- } \\
\text { väkirehu }\end{array}$} & \multicolumn{3}{|c|}{ Seoksen väkirehu } & \multicolumn{3}{|c|}{ Seosrehu } \\
\hline & & $\begin{array}{c}\text { Jakso } 1 \\
\text { Tärkkelys }\end{array}$ & $\begin{array}{c}\text { Jakso } 2 \\
\text { Kuitu }\end{array}$ & $\begin{array}{c}\text { Jakso3 } \\
\text { Tärkkelys }\end{array}$ & $\begin{array}{r}\text { Jakso } 1 \\
\text { Tärkkelys }\end{array}$ & $\begin{array}{c}\text { Jakso } 2 \\
\text { Kuitu }\end{array}$ & $\begin{array}{c}\text { Jakso } 3 \\
\text { Tärkkelys }\end{array}$ \\
\hline Kuiva-aine, $\mathrm{g} / \mathrm{kg}$ & 869 & 872 & 880 & 872 & 289 & 289 & 318 \\
\hline Tuhka & 68,1 & 62,3 & 61,3 & 58,7 & 67,4 & 66,3 & 66,7 \\
\hline Raakavalkuainen & 190 & 185 & 174 & 175 & 159 & 151 & 173 \\
\hline Raakarasva & 46,1 & 30,0 & 31,0 & 30,8 & - & - & \\
\hline Tärkkelys & 271 & 396 & 207 & 423 & 166 & 87 & 177 \\
\hline $\mathrm{NDF}$ & 224 & 207 & 333 & 221 & 402 & 457 & 397 \\
\hline $\mathrm{ME}, \mathrm{MJ} / \mathrm{kg} \mathrm{ka}$ & 12,8 & 12,2 & 11,8 & 12,2 & 11,9 & 11,7 & 11,9 \\
\hline OIV & 115 & 113 & 115 & 113 & 97 & 97 & 99 \\
\hline PVT & 30 & 27 & 22 & 27 & 19 & 14 & 33 \\
\hline
\end{tabular}


Taulukko 4. Jakson ja ruokinnan vaikutus rehun syöntiin, ravintoaineiden ja energian saantiin sekä koko ruokinnan ravintoainepitoisuuksiin.

\begin{tabular}{|c|c|c|c|c|c|c|c|c|c|c|c|}
\hline & \multicolumn{3}{|c|}{ Jakso $^{1}$} & \multicolumn{2}{|c|}{ Leikkauspiste } & \multicolumn{6}{|c|}{ Regressiokerroin } \\
\hline & $\begin{array}{c}1 \\
\text { Tärkkelys }\end{array}$ & $\begin{array}{c}2 \\
\text { Kuitu }\end{array}$ & $\begin{array}{c}3 \\
\text { Tärkkelys }\end{array}$ & Arvo & SE & $\begin{array}{l}\text { Lineaari- } \\
\text { nen }\end{array}$ & $\mathrm{SE}$ & $\mathrm{P}$-arvo & $\begin{array}{c}\text { Quadraat- } \\
\text { tinen }^{2}\end{array}$ & $\mathrm{SE}$ & P-arvo \\
\hline Seosrehu, kg ka/pv & 18,8 & 19,1 & 18,9 & 18,8 & 0,35 & 0,07 & 0,091 & 0,46 & & & \\
\hline Väkirehu robotista, $\mathrm{kg} \mathrm{ka/pv}$ & 5,51 & 5,51 & 5,39 & 5,58 & 0,226 & $-0,06$ & 0,027 & 0,04 & & & \\
\hline Yhteensä, kg ka/pv & 24,3 & 24,6 & 24,3 & 24,2 & 0,48 & $-0,04$ & 0,094 & 0,65 & & & \\
\hline Väkirehu yhteensä, $\mathrm{kg} \mathrm{ka/pv}$ & 13,4 & 13,5 & 13,3 & 13,5 & 0,31 & $-0,04$ & 0,047 & 0,38 & & & \\
\hline Raakavalkuainen, $\mathrm{kg} / \mathrm{pv}$ & 4,04 & 3,93 & 4,28 & 4,61 & 0,124 & $-0,80$ & 0,112 & $<0,001$ & 0,23 & 0,028 & $<0,001$ \\
\hline $\mathrm{NDF}, \mathrm{kg} / \mathrm{pv}$ & 8,78 & 9,95 & 8,70 & 5,19 & 0,282 & 4,80 & 0,271 & $<0,001$ & $-1,21$ & 0,067 & $<0,001$ \\
\hline Tärkkelys, kg/pv & 4,61 & 3,14 & 4,80 & 9,21 & 0,144 & $-6,16$ & 0,131 & $<0,001$ & 1,56 & 0,033 & $<0,001$ \\
\hline $\mathrm{OIV}, \mathrm{kg} / \mathrm{pv}$ & 2,45 & 2,49 & 2,49 & 2,44 & 0,050 & 0,02 & 0,009 & 0,056 & & & \\
\hline $\mathrm{ME} \mathrm{MJ/pv}$ & 293 & 293 & 294 & 292 & 5,9 & 0,42 & 1,127 & 0,71 & & & \\
\hline \multicolumn{12}{|c|}{ Koko ruokinnan pitoisuudet, g/kg ka } \\
\hline Raakavalkuainen & 166 & 159 & 176 & 196 & 0,5 & $-41,6$ & 0,52 & $<0,001$ & 11,6 & 0,13 & $<0,001$ \\
\hline $\mathrm{NDF}$ & 362 & 405 & 358 & 229 & 2,12 & 178 & 1,95 & $<0,001$ & $-44,9$ & 0,48 & $<0,001$ \\
\hline Tärkkelys & 189 & 127 & 197 & 384 & 1,89 & -261 & 1,94 & $<0,001$ & 66,2 & 0,48 & $<0,001$ \\
\hline OIV & 101 & 101 & 102 & 102 & 0,2 & $-1,92$ & 0,159 & $<0,001$ & 0,65 & 0,039 & $<0,001$ \\
\hline $\mathrm{ME} \mathrm{MJ/kg} \mathrm{ka}$ & 12,1 & 11,9 & 12,1 & 12,6 & 0,02 & $-0,68$ & 0,024 & $<0,001$ & 0,17 & 0,006 & $<0,001$ \\
\hline
\end{tabular}

${ }^{1}$ Aritmeettinen keskiarvo, ${ }^{2}$ Toisen asteen vaikutus

Taulukko 5. Jakson ja ruokinnan vaikutus maitotuotokseen, elopainoon ja rehun muuntosuhteeseen.

\begin{tabular}{|c|c|c|c|c|c|c|c|c|c|c|c|}
\hline & \multicolumn{3}{|c|}{ Jakso $^{1}$} & \multicolumn{2}{|c|}{ Leikkauspiste } & \multicolumn{6}{|c|}{ Regressiokerroin } \\
\hline & $\begin{array}{c}1 \\
\text { Tärkkelys }\end{array}$ & $\begin{array}{c}2 \\
\text { Kuitu }\end{array}$ & $\begin{array}{c}3 \\
\text { Tärkkelys }\end{array}$ & Arvo & SE & $\begin{array}{c}\text { Lineaari- } \\
\text { nen }\end{array}$ & SE & P-arvo & $\begin{array}{c}\text { Quadraat- } \\
\text { tinen }^{2}\end{array}$ & SE & P-arvo \\
\hline Maitotuotos, $\mathrm{kg} / \mathrm{pv}$ & 40,4 & 39,3 & 38,6 & 41,3 & 1,59 & $-0,92$ & 0,249 & $<0,001$ & & & \\
\hline $\mathrm{EKM}, \mathrm{kg} / \mathrm{pv}$ & 39,2 & 39,0 & 38,6 & 39,6 & 1,35 & $-0,33$ & 0,321 & 0,30 & & & \\
\hline Rasvapitoisuus, \% & 3,81 & 4,02 & 4,06 & 3,72 & 0,108 & 0,12 & 0,033 & $<0,001$ & & & \\
\hline Valkuaispitoisuus, $\%$ & 3,52 & 3,49 & 3,55 & 3,64 & 0,077 & $-0,16$ & 0,064 & 0,01 & 0,04 & 0,016 & $<0,01$ \\
\hline Urea, mg/dl & 24,6 & 25,1 & 30,0 & 28,6 & 1,71 & $-6,20$ & 1,871 & $<0,01$ & 2,21 & 0,464 & $<0,001$ \\
\hline Valkuaistuotos, $\mathrm{kg} / \mathrm{pv}$ & 1,40 & 1,35 & 1,35 & 1,52 & 0,074 & $-0,14$ & 0,069 & 0,04 & 0,03 & 0,017 & 0,097 \\
\hline Rasvatuotos, $\mathrm{kg} / \mathrm{pv}$ & 1,50 & 1,54 & 1,53 & 1,50 & 0,056 & 0,01 & 0,018 & 0,57 & & & \\
\hline Elopaino, $\mathrm{kg}$ & 663 & 666 & 671 & 658 & 13,8 & 4,37 & 0,691 & $<0,001$ & & & \\
\hline $\mathrm{EKM} \mathrm{kg/kg} \mathrm{ka}$ & 1,61 & 1,58 & 1,57 & 1,63 & 0,042 & $-0,02$ & 0,013 & 0,13 & & & \\
\hline
\end{tabular}

${ }^{1}$ Aritmeettinen keskiarvo, ${ }^{2}$ Toisen asteen vaikutus, EKM = energiakorjattu maitotuotos 
Taulukko 6. Jakson ja ruokinnan vaikutus syöntikäyttäytymiseen (seosrehu) ja lypsykäyttäytymiseen.

\begin{tabular}{|c|c|c|c|c|c|c|c|c|c|c|c|}
\hline & \multicolumn{3}{|c|}{ Jakso $^{1}$} & \multicolumn{2}{|c|}{ Leikkauspiste } & \multicolumn{6}{|c|}{ Regressiokerroin } \\
\hline & $\begin{array}{c}1 \\
\text { Tärkkelys }\end{array}$ & $\begin{array}{c}2 \\
\text { Kuitu } \\
\end{array}$ & $\begin{array}{c}3 \\
\text { Tärkkelys }\end{array}$ & Arvo & SE & $\begin{array}{l}\text { Lineaari- } \\
\text { nen }\end{array}$ & SE & P-arvo & $\begin{array}{l}\text { Quadraat- } \\
\text { tinen }^{2}\end{array}$ & $\mathrm{SE}$ & P-arvo \\
\hline \multicolumn{12}{|l|}{ Syöntikäyttäytyminen } \\
\hline Syöntikerrat, kpl/pv & 11,5 & 11,7 & 11,8 & 11,4 & 0,40 & 0,16 & 0,143 & 0,27 & & & \\
\hline Syöntiaika, min/pv & 242 & 242 & 214 & 213 & 13,2 & 42,0 & 12,86 & 0,002 & $-13,9$ & 3,18 & $<0,001$ \\
\hline Syöntinopeus, g /min & 249 & 251 & 287 & 280 & 16,3 & $-48,5$ & 15,97 & 0,003 & 17,0 & 3,95 & $<0,001$ \\
\hline Syöntinopeus, g ka/min & 80,1 & 82,1 & 93,1 & 87,1 & 5,29 & $-11,5$ & 5,20 & 0,03 & 4,50 & 1,29 & $<0,001$ \\
\hline \multicolumn{12}{|c|}{ Robottikäynnit, kpl/lehmä/päivä } \\
\hline Kaikki lypsyt yhteensä & 3,12 & 3,03 & 2,89 & 3,27 & 0,107 & $-0,12$ & 0,026 & $<0,001$ & & & \\
\hline Haku lypsylle & 0,15 & 0,12 & 0,16 & 0,14 & 0,057 & 0,006 & 0,022 & 0,77 & & & \\
\hline Vapaaehtoiset lypsyt & 2,97 & 2,91 & 2,73 & 3,12 & 0,139 & $-0,126$ & 0,033 & $<0,001$ & & & \\
\hline Läpikulut & 1,47 & 1,01 & 0,74 & 1,81 & 0,208 & $-0,37$ & 0,071 & $<0,001$ & & & \\
\hline Epäonnistuneet lypsyt & 0,10 & 0,12 & 0,10 & 0,11 & 0,042 & 0,001 & 0,019 & 0,95 & & & \\
\hline \multicolumn{12}{|l|}{ Lypsyväli, h } \\
\hline Poikimisesta alle $100 \mathrm{pv}^{3}$ & 7,9 & 8,1 & 8,4 & 7,6 & 0,41 & 0,26 & 0,110 & 0,02 & & & \\
\hline Poikimisesta $100-200 \mathrm{pv}^{3}$ & 7,7 & 8,1 & 8,4 & 7,3 & 0,72 & 0,37 & 0,173 & 0,05 & & & \\
\hline Poikimisesta yli $200 \mathrm{pv}^{3}$ & 9,1 & 10,2 & 10,9 & 8,3 & 1,31 & 0,88 & 0,334 & 0,03 & & & \\
\hline Maito, kg/lypsykerta & 13,0 & 13,0 & 13,4 & 12,8 & 0,38 & 0,157 & 0,085 & 0,07 & & & \\
\hline Lypsyaika, min/kerta & 6,84 & 6,87 & 7,07 & 6,69 & 0,363 & 0,12 & 0,059 & 0,04 & & & \\
\hline Max virtaus, $\mathrm{kg} / \mathrm{min}$ & 4,16 & 4,75 & 4,43 & 2,67 & 0,302 & 1,95 & 0,309 & $<0,001$ & $-0,45$ & 0,076 & $<0,001$ \\
\hline \multicolumn{12}{|l|}{ Virtaus keskimäärin, $\mathrm{kg} / \mathrm{min}$} \\
\hline Ensikot & 1,99 & 2,02 & 2,09 & 1,94 & 0,159 & 0,05 & 0,019 & 0,02 & & & \\
\hline Vanhemmat lehmät & 2,20 & 2,18 & 2,17 & 2,22 & 0,126 & $-0,02$ & 0,012 & 0,17 & & & \\
\hline
\end{tabular}

${ }^{1}$ Aritmeettinen keskiarvo, ${ }^{2}$ Toisen asteen vaikutus, ${ }^{3}$ Aika poikimisesta kokeen alkaessa 